\title{
The Investigation of the Barriers in Developing Green Building in Malaysia
}

\author{
Milad Samari ${ }^{1}$, Nariman Godrati ${ }^{1}$, Reza Esmaeilifar ${ }^{1}$, Parnaz $_{\text {Olfat }}{ }^{1} \&$ Mohd Wira Mohd Shafiei ${ }^{1}$ \\ ${ }^{1}$ School of Housing, Planning and Building, Universiti sains Malaysia, Malaysia \\ Correspondence: Milad Samari, School of Housing, Building and Planning, University Sains Malaysia (USM), \\ Penang 11800, Malaysia. E-mail: milad.s1366@gmail.com
}

\author{
Received: December 6, 2012 Accepted: January 1, $2013 \quad$ Online Published: January 15, 2013 \\ doi:10.5539/mas.v7n2p1 URL: http://dx.doi.org/10.5539/mas.v7n2p1
}

\begin{abstract}
Green building is the foundation of the sustainable construction development. Construction industry with the high contributes with gross domestic product, has undeniable impacts on the economy. Although Green buildings provide a wide range of benefits for the society, green building development suffers from different kinds of market barriers in developing countries including Malaysia. In order to meet green building development in Malaysia, this study aims to investigate the level of developing green building in the current situation, to find important key players and to identify, and to eliminate the important obstacles to green building development. In this research, the respondents were randomly selected from the professionals of Malaysian construction industry across the country and the method applied for collecting data is questionnaire survey. All the questionnaires were sent out to the respondents manually or through e-mail. A total of 673 sets of questionnaire were sent out and 167 (24.81\%) questionnaires were received. The quantitative method was used for analysing data through SPSS version 19. Based on the results, the level of developing green building in Malaysia is not satisfied and government has a key role in the development of green buildings in Malaysia. The main barriers can be listed as: lack of credit resources to cover up front cost, risk of investment, lack of demand as well as higher final price.
\end{abstract}

Keywords: green building, barriers, sustainable construction, Malaysia

\section{Introduction}

Recently, climate-change, energy crisis and increasing environmental pollution have made the sustainable development issue receive a great attention from the world (EPA, 2008). With growing concern of community about negative affect of human life on the environment, United Nation (1992) lunched the sustainable development document in Rio de Janerio in order to protect the environment (Parkin, 2000). Sustainable development tries to improve a quality of life for current people and future generation (Bossel, 1999). Many definitions of sustainable development are represented in the different contexts and scopes. Sustainable development can be defined "as growing natural and industrial resources which meet the energy need of the present times without settling the ability of next generations for meeting their needs in the same manner" (Hill, 2003). In addition, the United Nations (1987) explains that "sustainable Word development is a collection of methods in order to relieve poverty, create the equitable standards of living, satisfy the basic needs of all peoples, and set up sustainable political practices all while taking the steps essential to avoid irreversible damages to be natural environment in the long-term". One of the enormous and most important industries known as the largest polluters on the environment is the construction industry (Horvath, 1999). In addition, construction yields an annual output of US $\$ 4.6$ trillion, contributing to $8-10 \%$ of the global gross domestic product (GDP) encompassing a workforce of 120 million people and billions of transactions each day (McGraw-Hill, 2008). In US, construction comprises $13.4 \%$ of the $\$ 13.2$ trillion US GDP, in which commercial and residential building construction constitutes $6.1 \%$ of the GDP (AHKS, 2011). Therefore, it was revolved that the construction industry has direct and indirect important connections with the various aspects of sustainable development (Bourdeau, 1999).

\section{Implementation of Sustainable Development in the Construction Industry of Malaysia}

The construction industry of Malaysia is separated into two areas. The first area is general building, which includes residential building, non-residential building and civil engineering building. The second area is special 
trade works related to the construction include the activities of metal works, electrical works, and etc (AHKS, 2011). The estimated portion of construction industry in Malaysia is 5\% to $6 \%$ of the GDP at the end of 2012 , there is job opportunities for almost 1.03 million people that represent $8 \%$ of total workforce (CIDB, 2006). Estimation demand for construction under 9th Malaysia Plan is projected at RM 280 billion in the average of RM 56 billion per year. The projection is based on the estimation of RM 180 billion of government funded projects, RM 140 billion of private funded and RM 20 billion Public Finance Initiatives (PFI) in this stipulated time frame (CIDB, 2008). The construction industry makes up an important part of the Malaysian economy due to the interaction with other industry branches. The construction industry could be described as a substantial economic driver for Malaysia to achieve sustainable economy (Abdullah, 2004). According to the Master plan and 10th Malaysian plan, the government should apply sustainable development's goals in the construction industry.

Consequently, the various activities of the construction area have to be judged and examined when considering sustainable development. As a significant element in order to implement of sustainable development's goals in the construction industry, green building has an important role in achieving the aim of sustainable development (Fisk, 1988).

\section{Green Building}

Green building is an important area where cities can implement sustainability objectives. Green buildings are designed to reduce negative impacts on the environment while increasing the occupant health, by addressing these five categories:

- Sustainable site planning

- Safeguarding water and water efficiency

- Energy efficiency, renewable energy and lower greenhouse gas emissions

- Conservation and the reuse of materials and resources, and

- Improved health and indoor environmental quality

The environmental impact of buildings is often underestimated, while the perceived costs of green buildings are overestimated. Kats et al. (2003) comprehensively examined the costs and benefits of green buildings for the state of California in the United State. According to Kats, the average cost premium over just building to code is less than $2 \%$. The Kats report finds that "minimal increases in upfront costs of about $2 \%$ to support green design would, on average, result in life cycle savings of $20 \%$ of total construction costs more than ten times the initial investment". The majority of savings from green building are in the maintenance part and utility costs (CEA, 2011).

Table 1. Financial benefits of green buildings (per $\mathrm{ft} .2$ )

\begin{tabular}{ll}
\hline Category & 20-year Net Present Value \\
\hline Energy savings & $\$ 5.80$ \\
Emissions savings & $\$ 1.20$ \\
Water savings & $\$ 0.50$ \\
Operations and maintenance savings & $\$ 8.50$ \\
Productivity and health value & $\$ 36.90$ to $\$ 55.30$ \\
Subtotal & $\$ 52.90$ to $\% 71.30$ \\
Average extra cost of building green & $(-\$ 3.00$ to $\$ 5.00)$ \\
Total 20-year net benefit & $\$ 49.90$ to $\$ 66.30$ \\
\hline
\end{tabular}

Source: Capital E analysis, www.cap-e.com

Considering the statistics, reducing the amount of natural resources buildings consume and the amount of pollution given off are considered crucial for future sustainability. 


\section{Green Building Development in Malaysia}

In January 2009, Malaysia Green Building Index (GBI) was started at the Green Design Forum and organized by the Architectural Association of Malaysia (PAM). The Malaysian construction industry identified the necessity of green rating tool to improve and adapt itself to the tropical climate. GBI has been designed based on another international rating system such as BREEAM (Building Research Establishment Environmental Assessment Method); USA's LEED (Leadership in Energy and Environmental Design) and has been evaluated to be adapted to Malaysian climate conditions. It is an extensive rating system and environmental assessment used for appraising the environmental design and the performance of Malaysian buildings (ACEM, 2012).

Many experts (Atsusaka, 2003; Samari, 2012) believe that the role of governments in promoting green building is undeniable and effective. Rules and regulations should be replaced with enforcing new ones to support green building development. Governments can facilitate green building development by a variety of instruments. However, there is argument about the most effective and efficient instruments among the specialists and researchers. Some studies stated that market base intensives are both effective and efficient tools to address market failure together with non-market problems to improve the situation for green buildings development (Dennis, 2006). Shafii et al. (2005) point out that there are many impediments to developing sustainable development in Asia such as: Lack of awareness (people), Lack of training and education about sustainable design, higher cost, special materials, rules and regulation, lack of demonstration, lack of technology and lack of demand. Davis (2001) believed that most important barriers to green building development can be divided in three groups:

- Builder Incentives: Energy saving and worker productivity are popular benefit of green building. These benefits have positive effect for final owners and impose extra cost for builder. Hence, cost-effective is the main obstacle to green building development.

- Product Information and Sourcing: The common obstacle to green building development in developing countries is lack of green product's information for high-performance building systems. This obstacle leads to the developers to hire specialized consultants. Client Knowledge: the effective ways to remove this barrier are introduce a credible evidence of the advantages of green building and long-term studies to prove the benefits of green building.

\section{Methodology}

The construction industry in Asia has grown dramatically (Raftery et al., 2004; Bon et al., 2000). Global concerns on the environment and sustaining the world resources for the future generations have increased. Hence, Malaysia has launched initiatives for sustainable development in region. Malaysia's framework for sustainable development started when the following policies were had been formed (Chua et al., 2011):

- National Energy Policy 1979 (NEP79)

- National Depletion Policy 1980 (NDP80)

- Four Fuel Diversification Policy 1981 (4FDP81)

- Fifth Fuel Policy 2000 (5FP2000)

Base on the 10th Malaysia Plan, the government established the AFFIRM framework (Awareness, Faculty, Finance, Infrastructure, Research and Marketing) in order to promote the implementation of sustainable development criteria in the construction industry. Green building as part of sustainable development is under government's consideration to achieve better future for next generations (Sood et al., 2011). Thus, according to the plan adopted, this paper tries to investigate the level of developing green building, to find important key player and major barriers to green building development in Malaysia.

The methodology for this study includes collecting and analyzing data, namely initial data compiled by the questionnaires of the recognized sample. In an effort to eliminate barriers, to develop, and to promote green building in Malaysia, This paper seeks to address the following questions:

1) What is the level of developing green building in Malaysia?

2) Who plays a major role in developing green building in Malaysia?

3) What are important barriers against developing green building in Malaysia?

In this research, the respondents are randomly selected from the professionals of Malaysian construction industry across the country and the method used for collecting data is questionnaire survey. All the questionnaires were sent out to the respondents manually and through e-mail. A total of 673 sets of questionnaire were sent out and 
167 (24.81\%) questionnaires were received. Quantitative method has been used for analysing data through SPSS version 19. The questionnaire form is designed into the three following sections:

i. Part A: respondent's background.

ii. Part B: the awareness and perception about the green building.

iii. Part C: Green building development barriers

Reliability statistics used in this research is Cronbach Alpha. It is "determining the internal consistency or average correlation of items in a survey instrument to gauge its reliability" (Cronbach, 1951). The formula of Cronbach alpha:

$$
\alpha=\frac{\mathrm{N}^{-} C}{-\mathrm{v}+(\mathrm{n}-1) \cdot{ }^{-} \mathrm{c}}
$$

$\mathrm{N}=$ number of items

${ }^{-} \mathrm{C}=$ average inter-item covariance among the items

$\overline{-}_{\mathrm{V}}=$ average variance

The reliability of each part of the questionnaire was investigated to ensure that date is reliable. $\alpha$-Cronbach is between 0 and 1 . If $\alpha$-Cronbach is less than 0.5 , data are not reliable; therefore, the results which were gained through the data analysis are not applicable. In opposite, when $\alpha$-Cronbach is near 1 , data are reliable. In this research, a-Cronbach for part B is 0.909 and part C is 0.993 . The results were achieved through the SPSS software version 19.

Table 2. Reliability Statistics Part B

\begin{tabular}{cc}
\hline Cronbach's Alpha & N of Items \\
\hline 0.909 & 4 \\
\hline
\end{tabular}

Table 3. Reliability Statistics Part C

\begin{tabular}{cc}
\hline Cronbach's Alpha & N of Items \\
\hline 0.993 & 15 \\
\hline
\end{tabular}

\section{Data Analysis and Findings}

Understanding the obstacles to green building development will help to find ways to promote the green building market (Chan et al., 2009). The lack of expertise's knowledge in green building development creates an environment that lengthens development time frames (Choi, 2009). In addition, expert's knowledge is a key factor to promote sustainable building (Miyatake, 1996). The level of general awareness about sustainable buildings and their benefits among the construction professionals is low (bellow moderate). According to Table 4 construction industry suffers lack of expertise's knowledge in terms of green building; consequently it will lead to a low level of implementation of green building concept in construction projects.

Table 4. Professional's awareness, Company commitment and level of green building

\begin{tabular}{lccccccc}
\hline & $\mathrm{N}$ & Minimum & Maximum & Mean & Std. Deviation & \multicolumn{2}{c}{$\begin{array}{c}\text { Skewness } \\
\text { Statistic }\end{array}$} \\
\hline $\begin{array}{l}\text { Awareness of professionals } \\
\text { about the green building }\end{array}$ & 167 & 1 & 5 & 2.75 & 1.112 & .140 & .188 \\
$\begin{array}{l}\text { Company commitment to green } \\
\text { building }\end{array}$ & 167 & 1 & 4 & 2.23 & 1.045 & .332 & .188 \\
$\begin{array}{l}\text { The level of developing green } \\
\text { building in Malaysia }\end{array}$ & 167 & 1 & 5 & 2.36 & 1.131 & .772 & .188 \\
\hline
\end{tabular}

Government's involvement in developing green building is considered as one of the fundamental part and efficient ways (Varone et al., 2000; Qian et al., 2007; Atsusaka, 2003). According to 10th Malaysia Plan, the 
government should be promoting green building in residential and non-residential sectors. But professionals' points of view in terms of the level of developing green building in both sectors in Malaysia (Mean: 2.36) are not satisfactory. It is clear that the current strategy for developing green building in Malaysia is not effective.

This also accords with our earlier observations which showed that developing green building by current strategy is not satisfied. Table 8 shows that construction companies would not like to enter green market. This cause is related to the insecure market and high risk for investment. Table 9 illustrates that constructions companies (1: contractor, 2: Consultant, 3: Developer) have low interest in taking part in green projects. Forasmuch as construction companies are important deriver for developing green building, it can be conclude that construction companies are not willing to participate in green projects. This is regarded as another major obstacle facing the development of green buildings in Malaysia.

Tables 5 and 6 show the relationship between professionals's awareness and their education levels. This result ( $\mathrm{R}$ Square: 0.859 , sig: 0.000) indicates that by increasing the respondents' education level their awareness about green homes rises. Therefore, raising the education level among the experts will lead to increasing construction companies' interest in the green building market. It also helps them practice more environmentally friendly methods in their future projects as part of their responsibility to the society. By applying this strategy, level of green features applied by professionals in the buildings will increase dramatically due to high concern on projects' environmental impacts. This aim can be achieved by establishing training courses and periodical seminars for experts in order to promote their knowledge of green building (Samari et al., 2012).

Table 5. Correlation model

\begin{tabular}{ccccc}
\hline Model & $\mathrm{R}$ & R Square & Adjusted R Square & Std. Error of the Estimate \\
\hline 1 & $.927^{\mathrm{a}}$ & .859 & .859 & .418 \\
\hline
\end{tabular}

a. Predictors: (Constant), Education level

Dependent Variable: What is the awareness of professionals about the green building?

Table 6. Coefficients ${ }^{\mathrm{a}}$

\begin{tabular}{|c|c|c|c|c|c|c|}
\hline & \multirow{2}{*}{ Model } & \multicolumn{2}{|c|}{ Unstandardized Coefficients } & \multirow{2}{*}{$\begin{array}{c}\text { Standardized Coefficients } \\
\text { Beta }\end{array}$} & \multirow{2}{*}{$\mathrm{t}$} & \multirow{2}{*}{ Sig. } \\
\hline & & $\mathrm{B}$ & Std. Error & & & \\
\hline \multirow[t]{2}{*}{1} & (Constant) & .605 & .075 & & 8.080 & .000 \\
\hline & Education level & 1.081 & .034 & .927 & 31.754 & .000 \\
\hline
\end{tabular}

a. Dependent Variable: What is the awareness of professionals about the green building?

Table 7. Cross tabulation between firm categories and company commitment

\begin{tabular}{|c|c|c|c|c|c|c|c|c|}
\hline & \multicolumn{4}{|c|}{$\begin{array}{l}\text { How do you describe your company } \\
\text { commitment to green building? }\end{array}$} & \multirow[b]{2}{*}{ Total } & \multirow[b]{2}{*}{ Mean } \\
\hline & & & very Low & Low & Moderate & High & & \\
\hline \multirow{6}{*}{$\begin{array}{l}\text { Firm } \\
\text { category }\end{array}$} & Contractor & Count & 39 & 13 & 0 & 0 & 52 & 1.25 \\
\hline & & $\%$ within Firm category & $75.0 \%$ & $25.0 \%$ & $.0 \%$ & $.0 \%$ & $100.0 \%$ & \\
\hline & Consultant & Count & 0 & 39 & 39 & 0 & 78 & 2.50 \\
\hline & & $\%$ within Firm category & $.0 \%$ & $50.0 \%$ & $50.0 \%$ & $.0 \%$ & $100.0 \%$ & \\
\hline & Developer & Count & 12 & 0 & 0 & 25 & 37 & 3.02 \\
\hline & & $\%$ within Firm category & $32.4 \%$ & $.0 \%$ & $.0 \%$ & $67.6 \%$ & $100.0 \%$ & \\
\hline \multirow[t]{2}{*}{ Total } & & Count & 51 & 52 & 39 & 25 & 167 & \\
\hline & & $\%$ within Firm category & $30.5 \%$ & $31.1 \%$ & $23.4 \%$ & $15.0 \%$ & $100.0 \%$ & \\
\hline
\end{tabular}

According to Tables 7 and 8 , Chi-square $=210.924, P=0.00$, there is statistically significant association between firm categories and company commitment. Based on the firms' category, developers (Mean=3.02) have more commitment to green building concept. Although, this commitment is slightly higher than moderate, it might be effective to stimulate consultants and contractors to be more obsessed with environment as they can ask consultants and contractors to practice environmentally friendly in their projects. 
Table 8. Chi-square tests

\begin{tabular}{cccc}
\hline & Value & df & Asymp. Sig. (2-sided) \\
\hline Pearson Chi-Square & $210.924^{\mathrm{a}}$ & 6 & .000 \\
Likelihood Ratio & 237.493 & 6 & .000 \\
Linear-by-Linear Association & 67.526 & 1 & .000 \\
N of Valid Cases & 167 & & \\
\hline
\end{tabular}

a. 0 cells $(.0 \%)$ have expected count less than 5 . The minimum expected count is

5.54 .

According to the previous research, experts believed that government has important role to promote green building (Varone et al., 2000; Fisher et al., 1989; Sutherland, 1991; Golove et al., 1996; Ofori, 2006). In Malaysian construction context, government plays a significant role to promote green building. Government is the key player in term of promoting green building in the construction industry. Government can affect the construction industry by a variety of instruments. Regulatory instruments and incentive instruments are the main tools for governments to develop green building (Yung et al., 2002).

A combination of legislations to enforce companies and market to sustainable development and incentive package for construction firms that practice sustainability in their projects is the best approach that can be applied by governments. Contractors as next major players undoubtedly can promote sustainability and minimize environmental impacts in construction field by using new technologies and environmentally friendly products, and applying waste management Life Cycle Assessment method in construction stage.

Table 9. Major role in developing green building in Malaysia

\begin{tabular}{clcccc}
\hline & Frequency & Percent & Valid Percent & Cumulative Percent \\
\hline Valid & Contractor & 26 & 15.5 & 15.6 & 15.6 \\
& Consultant & 52 & 31.1 & 31.1 & 46.7 \\
& Developer & 13 & 7.7 & 7.8 & 54.5 \\
& Government & 76 & 45.5 & 45.5 & 100.0 \\
& Total & 167 & 100.0 & 100.0 & \\
\hline
\end{tabular}

Table 10. Cross tabulation between work experience and major role in developing green building in Malaysia

\begin{tabular}{|c|c|c|c|c|c|c|c|}
\hline & & & \multicolumn{4}{|c|}{$\begin{array}{c}\text { Who plays a major role in developing green } \\
\text { building in Malaysia? }\end{array}$} & \multirow[t]{2}{*}{ Total } \\
\hline & & & Contractor & Consultant & Developer & Government & \\
\hline \multirow{6}{*}{$\begin{array}{c}\text { Work } \\
\text { experience } \\
\text { in } \\
\text { construction } \\
\text { project }\end{array}$} & \multirow{2}{*}{$\begin{array}{l}x<5 \\
\text { years }\end{array}$} & Count & 26 & 52 & 13 & 0 & 91 \\
\hline & & $\%$ within Work experience & $28.6 \%$ & $57.1 \%$ & $14.3 \%$ & $.0 \%$ & $100.0 \%$ \\
\hline & \multirow{2}{*}{$\begin{array}{c}5 \leq x<10 \\
\text { years }\end{array}$} & Count & 0 & 0 & 0 & 52 & 52 \\
\hline & & $\%$ within Work experience & $.0 \%$ & $.0 \%$ & $.0 \%$ & $100.0 \%$ & $100.0 \%$ \\
\hline & \multirow{2}{*}{$\begin{array}{l}x \geq 10 \\
\text { years }\end{array}$} & Count & 0 & 0 & 0 & 24 & 24 \\
\hline & & $\%$ within Work experience & $.0 \%$ & $.0 \%$ & $.0 \%$ & $100.0 \%$ & $100.0 \%$ \\
\hline \multirow{2}{*}{\multicolumn{2}{|c|}{ Total }} & Count & 26 & 52 & 13 & 76 & 167 \\
\hline & & $\begin{array}{l}\% \text { within Work experience } \\
\text { in construction project }\end{array}$ & $15.6 \%$ & $31.1 \%$ & $7.8 \%$ & $45.5 \%$ & $100.0 \%$ \\
\hline
\end{tabular}

Base on Master Plan and 10th Malaysia Plan, government has to develop green building concept in order to preserve natural resources and enhance urban life quality for the residents. Figure below shows three steps which government can take to develop green concept in construction industry by identifying the barriers that hinder green building development in the country. 


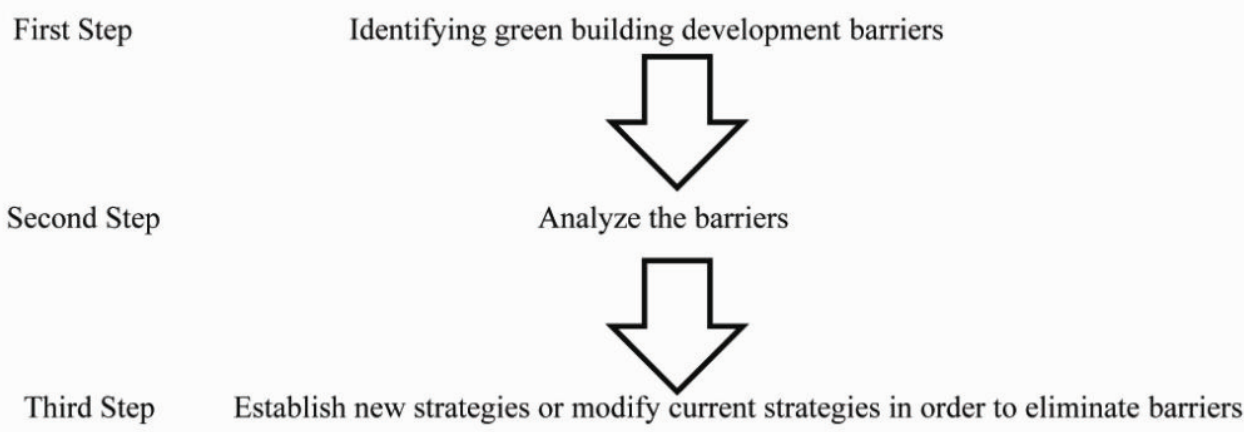

Table 11. Barriers

\begin{tabular}{ll}
\hline Code & Barriers \\
\hline B1 & Lack of building codes and regulation \\
B2 & Lack of incentives \\
B3 & Higher investment cost \\
B4 & Risk of investment \\
B5 & Higher final price \\
B6 & Lack of credit resources to cover up front cost \\
B7 & Lack of Public awareness \\
B8 & Lack of demand \\
B9 & Lack of strategy to promote green building \\
B10 & Lack of design and construction team \\
B11 & Lack of expertise \\
B12 & Lack of professional knowledge \\
B13 & Lake of database and information (case study) \\
B14 & Lack of technology \\
B15 & Lack of government support \\
\hline
\end{tabular}

To explore which barriers to green building are the most important compared to other ones in construction industry in Malaysia, respondents were asked to rate their importance in different levels for each item. Data were analyzed based on the Mean and Median (Table 13). These measures of dispersion are used to assess the homogenous or heterogeneous nature of the collected data (Bernard, 2000).

Table 12. Barrier's descriptive statistics

\begin{tabular}{cccccccccc}
\hline \multirow{2}{*}{ Code } & Rank & Range & Minimum & Maximum & Mean & Medan & Variance & \multicolumn{2}{c}{ Skewness } \\
\cline { 3 - 9 } & & Statistic & Statistic & Statistic & Statistic & Statistic & Statistic & Statistic & Std. Error \\
\hline B1 & 5 & 4 & 1 & 5 & 3.44 & 4 & 1.477 & -.416 & .188 \\
B2 & 11 & 4 & 1 & 5 & 3.05 & 3 & 1.280 & .171 & .188 \\
B3 & 10 & 4 & 1 & 5 & 3.06 & 3 & .984 & -.159 & .188 \\
B4 & 2 & 4 & 1 & 5 & 3.68 & 4 & 1.449 & -.717 & .188 \\
B5 & 4 & 4 & 1 & 5 & 3.58 & 4 & 1.471 & -.521 & .188 \\
B6 & 1 & 4 & 1 & 5 & 3.80 & 4 & 1.762 & -.606 & .188 \\
B7 & 13 & 4 & 1 & 5 & 2.59 & 3 & 1.134 & .451 & .188 \\
B8 & 3 & 4 & 1 & 5 & 3.61 & 4 & 1.784 & -.829 & .188 \\
B9 & 9 & 4 & 1 & 5 & 3.10 & 3 & 1.657 & -.283 & .188 \\
B10 & 8 & 4 & 1 & 5 & 3.13 & 3 & 1.344 & -.002 & .188 \\
B11 & 14 & 4 & 1 & 5 & 2.67 & 3 & 1.114 & .257 & .188 \\
B12 & 6 & 4 & 1 & 5 & 3.21 & 3 & 1.239 & -.132 & .188 \\
B13 & 15 & 4 & 1 & 5 & 2.44 & 2 & 1.609 & .439 & .188 \\
B14 & 12 & 4 & 1 & 5 & 2.83 & 3 & 1.506 & -.198 & .188 \\
B15 & 7 & 4 & 1 & 5 & 3.14 & 3 & 1.047 & -.314 & .188 \\
\hline
\end{tabular}


In Malaysia, for developing green building government has just introduced two incentives such as tax exemption and stamp duty (ACEM, 2012). According to the finding the current incentives are not effective enough to encourage construction firms to enter green building development. Financial incentives are also not able to recoup the high upfront cost of green buildings and make it more affordable for construction companies. In 2007, Bandy et al. have shown that that higher upfront cost (new design, technology and construction method) is the main impediment to green building development. Governmental financial incentives have essential rules to provide low risk and affordable financial resources for green developers in both commercial and residential sectors. Public awareness about green building has been an important component that led to high demand (Toronto green development standard, 2006). Improving public awareness about green building leads to better informed consumers who will demand better products from companies and encourage more green building development. In addition, cost savings can potentially increase a consumer's willingness to pay extra. To achieve sustainable green home development and to make balance between green home owners' benefits and construction companies' profits are critical issues.

\section{Conclusion}

This paper reports the results of a questionnaire survey conducted in Malaysia on the barriers of the green building development. The level of green building development from professionals' point of view has been investigated and the most important barriers have been identified. The findings suggest that government roles especially incentive instruments such as structural incentives, subsidy and rebate program, tax incentive scheme, low interest mortgage loan, voluntary rating system and market and technology assistance are the significant drives for eliminating barriers to green building development.

\section{Acknowledgement}

This work was supported in part by the Fellowship Scheme of Universiti Sains Malaysia.

\section{References}

Abdulllah, F. M., Chiet, V. C., Anuar, K., \& Shen, T. T. (2004). An Overview on the Growth and Development of the Malaysian Construction Industry. Workshop on Construction Contract Management, University Teknologi, Malaysia.

ACEM Directory (Association consulting engineers Malaysia). (2012). Retrieved from http://www.acem.com.my/index.php?option=com_content\&task=view\&id=58\&Itemid=1

AHKS report. (2011). Malaysian-German Chamber of Commerce, Market Watch, the Construction Sector. Retrieved

from

http://malaysia.ahk.de/fileadmin/ahk_malaysia/Bilder/Others/Market_Watch_Malaysia_Construction_Indus try_2011.pdf

Atsusaka, N. (2003). Growing the Green Building Industry in Lane County - a report for the lane county sustainable business and job project, report prepared from the program for Watershed and Community Health, Institute for a Sustainable Environment, University of Oregon, USA.

Bandy, R., Danckaert, C., Fetscher, G., Holmes, B., Gale, M., Mirsky, M., ... Stewart, S. (2007). Leed in upstate New York: an exploration of barriers, resources and strategies. USGBC New York Upstate chapter and environment finance center, EPA region 2, Maxwell capstone project.

Bernard, H. R. (2000). Social Research Methods: Qualitative and Quantitative Approaches. London: Sage Publishing Ltd.

Bon, R., \& Crosthwaite, D. (2000). The Future of International Construction. London: Thomas Telford Limited.

Bossel, H. (1999). Indicators for Sustainable Developments - Theory, Method, Application. International Institute for Sustainable Development, pp 2-8.

Bourdeau, L. (1999). Sustainable development and the future of construction: a comparison of vision from various countries. Journal of Building Research and Information, 27(6), 354-366. http://dx.doi.org/10.1080/096132199369183

Capital E Analysis. (2011). Green building, redirecting our campus toward environmental sustainability. Retrieved from http://www.colbysawyer.edu/assets/pdf/GreenBuildingPoster.pdf

Chan, E. W. W., Qian, K. Q., \& Lam, I. P. (2009). The market for green building in developed Asian cities: the perspectives of building designers. Energy Policy, 37, 3061-3070. http://dx.doi.org/10.1016/j.enpol.2009.03.057 
Choi, C. (2009). Removing Market Barriers to Green Development: Principles and Action Projects to Promote Widespread Adoption of Green Development Practices. JOSRE, 1(1), 107-138.

Chua, S. C., \& Oh, T. H. (2011). Green progress and prospect in Malaysia. Renewable and Sustainable Energy Reviews, 15, 2850-2861. http://dx.doi.org/10.1016/j.rser.2011.03.008

CIDB. (2006). Strategic Recommendations for Improving Environmental Practices in Construction Industry. Construction Industry Development Board (CIDB) Malaysia. Kuala Lumpur.

Cronbach, L. J. (1951). Coefficient alpha and the internal structure of tests. Psychometrika, 16, 297-334. http://dx.doi.org/10.1007/BF02310555

Davis. A. (2001). Barriers to Building Green. Retrieved from http://www.greenbiz.com/blog/2001/11/01/barriers-building-green

Dennis, K. (2006). The Compatibility of Economic Theory and Proactive Energy Efficiency Policy. The Electricity Journal, 19(7), 58-73. http://dx.doi.org/10.1016/j.tej.2006.07.006

Economic Planning Unit. (2010). The Tenth Malaysia Plan 2011-2015. Malaysia.

EPA. (2008). Report on the Environment. Retrieved from http://www.epa.gov/greenbuilding/pubs/whybuild.htm

Fisher, A. C., \& Rothkop, M. H. (1989). Market failure and energy policy: a rationale for selective conservation. Energy Policy, 17(4), 397-406. http://dx.doi.org/10.1016/0301-4215(89)90010-4

Fisk, W., \& Rosenfeld, A. (1998). Potential nationwide improvements in productivity and health from better indoor environments. Berkeley: Lawrence Berkeley National Laboratory.

Golove, W. H., \& Eto, J. H. (1996). Market barriers to energy Efficiency: a critical reappraisal of the rationale for public policies to promote energy efficiency, report done by Energy \& Environment Division. Lawrence Berkeley National Laboratory, University of California, USA.

Government of Malaysia, (2006). Malaysian 9th Plan, Chapter 21: 437.

Hill, M. (2003). Dictionary of Scientific and Technical Terms. USA, McGraw-Hill Publication.

Horvath, A. (1999). Construction for Sustainable Development - A Research and Educational Agenda. Submitted for the Berkeley-Stanford Construction Engineering and Management Workshop, August 26-28, 1999.

Kats, G., \& Capital, E. (2003). The cost and financial benefits of green buildings: a report to California's sustainable building task force, developed for the Sustainable Building Task Force. California, USA.

Malaysian Construction Outlook. (2008). Presentation by Business Development Division, Construction Industry Development Board (CIDB), August 2008.

Master Plan(Construction Industry of Malaysia), 2006-2015 (CIMP). (2006).

McGraw-Hill Construction. (2008). Key Trends in the European and U.S. Construction Marketplace: Smart Market Report.

Miyatake, Y. (1996). Technology development and sustainable construction. Journal of Management in Engineering, 12(4), 23-27. http://dx.doi.org/10.1061/(ASCE)0742-597X(1996)12:4(23)

Ofori, G. (2006). Attaining sustainability through construction procurement in Singapore. CIB W092-Procurement Systems Conference 2006, Salford, UK.

Parkin, S. (2000). Context and drivers for operationalizing sustainable development. Proceedings of The Institution of Civil Engineers: Civil Engineering, 138, 9-15. http://dx.doi.org/10.1680/cien.2000.138.6.9

Qian, Q. K., \& Chan, E. H. W. (2007). Government measures for promoting Building Energy Efficiency (BEE): a comparative study between China and some developed countries. The CRIOCM2007 International Symposium on Advancement of Construction Management and Real Estate, Sydney, Australia.

Raftery, J., Anson, M., Chiang, Y. H., \& Sharma, S. (2004). Regional overview. In: Chiang, Y.H., et al. (Eds.). The Construction Sector in Asian Economics. London: Spon Press.

Samari, M., Ghodrati, N., \& Shafiei, M. V. M. (2012). Implementation of Sustainable Development in Construction Industry in Penang Island, International Conference on Civil Engineering AICCE'12.

Samari, M. (2012). Sustainable Development in Iran: a Case Study of Implementation of Sustainable Factors in Housing Development in Iran. IPEDR, 37. Singapore: ACSIT Press. 
Shafii, F., \& Othman, M. Z. (2005). Sustainable Building and Construction in South-East Asia, Proceedings of The Conference on Sustainable Building South-East Asia, Malaysia, 11-13.

Sood, M. S., Chua, H. K. M., \& Peng, Y. L. (2011). Sustainable Development in the Building Sector: Green Building Framework in Malaysia. ST-8: Best Practices \& SD in Construction.

Sutherland, R. J. (1991). Market barriers to energy-efficient investments. Energy Journal, 12(3), 15-34. http://dx.doi.org/10.5547/ISSN0195-6574-EJ-Vol12-No3-3

Toronto green development standard report. (2006). Retrieved from http://www.toronto.ca/planning/environment/greendevelopment.htm

Varone, F., \& Aebischer, B. (2000). Energy efficiency: the challenges of policy design. Energy Policy, 29, 615-629. http://dx.doi.org/10.1016/S0301-4215(00)00156-7

World Commission on Environment and Development. (1987). Our Common Future. Oxford: Oxford University Press.

Yung, E., \& Chan, E. H. W. (2002). Evaluating Environmental Management Policies: International Trend Development of Construction Management and Real Estate; 100-111. 